\title{
Altered $\beta$-catenin expression in oral mucosal dysplasia: a comparative study
}

\author{
Brunno Santos de Freitas SILVA', Caroline Alves de CASTRO ${ }^{2}$, Sandra Lúcia Ventorin VON ZEIDLER ${ }^{3}$, Suzana \\ Cantanhede Orsini Machado de SOUSA ${ }^{4}$, Aline Carvalho BATISTA ${ }^{1}$, Fernanda Paula YAMAMOTO-SILVA ${ }^{1}$ \\ 1- Universidade Federal de Goiás, Faculdade de Odontologia, Departamento de Ciências Estomatológicas, Goiânia, GO, Brazil. \\ 2- Universidade Federal de Goiás, Faculdade de Odontologia, Goiânia, GO, Brazil. \\ 3- Universidade Federal do Espírito Santo, Departamento de Patologia, Vitória, ES, Brazil. \\ 4- Universidade de São Paulo, Faculdade de Odontologia, Departamento de Patologia Oral, São Paulo, SP, Brazil.
}

\begin{abstract}
Corresponding address: Brunno Santos de Freitas Silva - Departamento de Ciências Estomatológicas, Faculdade de Odontologia, Universidade Federal de Goiás - Praça Universitária, s/n. - Setor Universitário - GO - Goiânia - Brazil - 74605-220 - Phone: +55 (62) $3209-6249$ / +55 (62) $3434-4394$ - e-mail: brunno.santosfreitas@gmail.com
\end{abstract}

Submitted: April 12, 2015 - Modification: July 4, 2015 - Accepted: August 6, 2015

\section{ABSTRACT}

\begin{abstract}
O bjective: The current study aimed to investigate the $\beta$-catenin expression in oral leukoplakia (OL) with different degrees of epithelial dysplasia and normal oral mucosa. Material and Methods: Formalin-fixed, paraffin-embedded tissue samples of 39 OL (mild dysplasia $n=19$, moderate dysplasia $n=13$, and severe dysplasia $n=7$ ), and 10 normal oral mucosa (control group) were submitted to immunohistochemical reactions to anti- $\beta$-catenin primary antibody. A qualitative $\beta$-catenin analysis was performed based on the percentage of positive cells. The cellular location and the epithelial layer were also considered. The Chi-square test and the Fisher's exact test were used to verify possible differences in the $\beta$-catenin expression among the OL groups. A p-value of $<0.05$ was considered statistically significant. Results: Membranous expression of $\beta$-catenin in parabasal and basal layers was gradually lost in the higher degrees of epithelial dysplasia. In normal oral mucosa, $\beta$-catenin was detected only in the cytoplasmic membrane. However, a significant increase in cytoplasmic $\beta$-catenin could be observed between mild and moderate dysplasia (Fisher Exact test $-p<0.001)$ and between mild and severe dysplasia $(p<0.001)$. Conclusions: The $\beta$-catenin cytoplasmic expression observed in this study may represent the initial stage of modifications in the E-cadherin-catenin complex, along with morphological cellular changes.
\end{abstract}

Keywords: Beta-catenin. Oral dysplasia. Oral cancer. Oral leukoplakia.

\section{NTRODUCTI ON}

Disturbances in cell adhesion and cytoskeleton dynamics could signal an early event in oral carcinogenesis $^{8}$. These alterations, including loss of cell-cell adhesion and increase in cell motility, occur in the epithelial-mesenchymal transition (EMT) process $^{20}$. EMT transition is a biological process characterized by changes in cellular phenotype and function, undergone by cells from epithelial phenotype to motile mesenchymal phenotype ${ }^{13}$. However, this transition is also seen in tumor progression and metastasis ${ }^{10}$. EMT is activated by wide-ranging stimuli provided by growing factors and hypoxia, as well as by transcription factors such as Snail, Slug and Twist ${ }^{13}$.
Twist is an important negative regulator of the transmembrane adhesion protein $\mathrm{E}$-cadherin; it is believed that the downregulation of $\mathrm{E}$-cadherin is the central event of $\mathrm{EMT}^{29}$. E-cadherin is located in the epithelial cell regions of cell-cell adhesion known as adherens junctions ${ }^{4}$. E-cadherin loss leads to the disassembly of adherens junctions, increased tumor cell mobility and invasiveness ${ }^{23}$.

$\beta$-catenin is a bifunctional protein that acts in cell adhesion and as a transcription factor activated by the Wnt pathway ${ }^{6}$. E-cadherin interacts with $\beta$-catenin through intercellular connections to form stable adhesions; the dissociation of this complex is involved in malignant progression ${ }^{5}$. Downregulation of membranous $\mathrm{E}$-cadherin and cytoplasmic or nuclear accumulation of $\beta$-catenin 
have been previously implicated in the loss of differentiation and more aggressive phenotypes, in a variety of different cancers ${ }^{7,18}$.

Recently, it was suggested that the altered expression of E-cadherin/ $\beta$-catenin complex is involved in growth regulation and phenotype changes of both dysplastic oral epithelia and malignant oral epithelia ${ }^{17}$. According to Kaur, et al. ${ }^{15}$ (2013), losses of E-cadherin and $\beta$-catenin altered expressions are considered early events in oral carcinogenesis. Moreover, an aberrant expression of $\beta$-catenin was also found in actinic cheilitis cases and in OSCC of the lip, indicating that altered patterns of this protein are also present in oral lesions with actinic etiology ${ }^{26}$. Lo Muzio, et al. ${ }^{19}$ (2009) observed an altered expression of catenin in a large group of dysplastic lesions of the oral mucosa. However, they suggest that the role of catenin expression as a prognostic marker in dysplastic oral lesions seems to be restricted.

In our previous study, we observed that the downregulation of E-cadherin promoted by Twist could be involved in oral carcinogenesis through the Wnt pathway ${ }^{8}$. Accordingly, the current study aimed at testing this hypothesis by investigating the $\beta$-catenin immunohistochemical expression in oral leukoplakia (OL) with different degrees of epithelial dysplasia and normal oral mucosa.

\section{MATERIAL AND METHODS}

This study was approved by the Human Ethics Committee of the Institutional Review Board (Committee approval no. 015/2010).

\section{Specimens}

Formalin-fixed, paraffin-embedded tissue samples of 39 OL (mild dysplasia $n=19$, moderate dysplasia $n=13$, and severe dysplasia $n=7$ ) and 10 normal oral mucosa from 18 males and 21 females were collected from the Laboratory of Oral Pathology of the Federal University of Goiás and from the Laboratory of Oral Pathology of the University of São Paulo. All the biopsed specimens were collected in the period of 1998-2012. The clinical pathological data from all studied cases were described in Figure 1 . The samples were submitted to $5 \mu \mathrm{m}$ histological sections for routine staining with hematoxylin eosin (H\&E) and analyzed under light microscopy. The histological grades of oral dysplasia were reviewed by two independent oral pathologists in blind fashion, according to the World Health Organization $(\mathrm{WHO})^{3}$. Any disagreement in the findings was discussed among the pathologists to render a final evaluation.

\section{I mmunohistochemistry}

The immunohistochemical reactions were performed using $3 \mu \mathrm{m} 4 \%$ formalin-fixed slides followed by dewaxing and rehydration in an ethanol series. Antigen retrieval consisted of immersing the sections in a solution of $10 \mathrm{mM}$ monohydrated citrate buffer solution ( $\mathrm{pH}$ 6.0) and heating them in a water bath at $95^{\circ} \mathrm{C}$ for 30 minutes. Endogenous peroxidase activity was blocked with $6 \%$ hydrogen peroxide and a methanol solution, in two baths of 15 minutes each at room temperature. After washing with Tris buffer $(\mathrm{pH} \mathrm{7.4)}$, the slides were incubated with anti- $\beta$-catenin (E-5; Santa Cruz Biotechnology, Santa Cruz, CA, US, dilution $1: 100)$ primary antibody overnight at $4^{\circ} \mathrm{C}$. The negative control was obtained by omitting the specific primary antibody during the reaction. The slides were then exposed to avidin-biotin complex (LSAB-Kit + HRP; DakoCytomation, Carpinteria, CA, USA) and to 3,3'-diaminobenzidine chromogen (DAB+; DakoCytomation, Carpinteria, CA, USA). The sections were counterstained with Meyer hematoxylin, dehydrated in ethanol, cleared in xylene, and mounted.

A qualitative $\beta$-catenin analysis was performed based on the percentage of positive cells, considering positive only those specimens that presented $25 \%$ or more cells presenting $\beta$-catenin expression. The cellular location (cytoplasmic membrane, cytoplasm and nucleus) and the epithelial layer (basal, parabasal and spinous cell layers) were also considered. $\beta$-catenin immunohistochemical expressions were analyzed by two independent blind and calibrated observers under light microscopy at 200-fold magnification.

\section{Statistical analysis}

The data was tabulated with Microsoft Excel software, and statistical analysis was performed by Statistical Package for Social Sciences software (SPSS 16, Headquarters, USA). The Chi-square test and the Fisher's exact test were used to verify possible differences in the $\beta$-catenin expression among the OL groups. A p-value of $<0.05$ was considered statistically significant.

\section{RESULTS}

In general, $\beta$-catenin immunohistochemical staining was observed in the cytoplasmic membrane in all OL dysplastic groups $(n=39$; mild, moderate and severe dysplasia) (Figure 2 ). In mild, moderate and severe dysplasia, $\beta$-catenin staining was also detected in the cytoplasm in $51.2 \%(n=20)$ of OL cases (Figure 2, A-F). In addition, membranous expression of $\beta$-catenin in parabasal and basal layers was gradually lost in the higher degrees of epithelial dysplasia (Figure 2, B, D, F, H). 


\begin{tabular}{|c|c|c|c|c|c|c|c|}
\hline Case & Gender & $\begin{array}{c}\text { Age patient } \\
\text { (year) }\end{array}$ & $\begin{array}{c}\text { Anatomical } \\
\text { site }\end{array}$ & $\begin{array}{c}\text { Smoking } \\
\text { habit }\end{array}$ & $\begin{array}{c}\text { Alcohol } \\
\text { consuption }\end{array}$ & $\begin{array}{c}\text { Clinical } \\
\text { diagnosis }\end{array}$ & $\begin{array}{c}\text { Histological } \\
\text { grade } \\
\text { (Epithelial } \\
\text { dysplasia) }\end{array}$ \\
\hline 1 & $M$ & 47 & $\begin{array}{l}\text { Buccal } \\
\text { mucosa }\end{array}$ & yes & yes & Leukoplakia & Mild \\
\hline 2 & $F$ & 70 & $\begin{array}{l}\text { Floor of } \\
\text { mouth }\end{array}$ & ---- & ---- & Leukoplakia & Severe \\
\hline 3 & $F$ & 53 & $\begin{array}{l}\text { Buccal } \\
\text { mucosa }\end{array}$ & yes & no & Leukoplakia & Moderate \\
\hline 4 & $\mathrm{~F}$ & 42 & Palate & yes & no & Leukoplakia & Mild \\
\hline 5 & $M$ & 50 & Palate & yes & no & Leukoplakia & Moderate \\
\hline 6 & $\mathrm{M}$ & 61 & Tongue & yes & no & Leukoplakia & Moderate \\
\hline 7 & $M$ & 59 & Tongue & yes & no & Leukoplakia & Mild \\
\hline 8 & $\mathrm{~F}$ & 71 & Tongue & yes & no & Leukoplakia & Mild \\
\hline 9 & $\mathrm{~F}$ & 49 & Tongue & no & no & Leukoplakia & Mild \\
\hline 10 & M & 64 & Gingiva & yes & yes & Leukoplakia & Mild \\
\hline 11 & $\mathrm{~F}$ & 49 & $\begin{array}{l}\text { Buccal } \\
\text { mucosa }\end{array}$ & yes & no & Leukoplakia & Moderate \\
\hline 12 & $\mathrm{~F}$ & 53 & $\begin{array}{l}\text { Buccal } \\
\text { mucosa }\end{array}$ & yes & no & Leukoplakia & Mild \\
\hline 13 & $\mathrm{~F}$ & 57 & ---- & ---- & ---- & Leukoplakia & Moderate \\
\hline 14 & $M$ & 66 & ---- & ---- & ---- & Leukoplakia & Moderate \\
\hline 15 & $M$ & 58 & ---- & ---- & --- & Leukoplakia & Mild \\
\hline 16 & $M$ & 44 & Gingiva & yes & yes & Leukoplakia & Mild \\
\hline 17 & $F$ & 63 & $\begin{array}{l}\text { Floor of } \\
\text { mouth }\end{array}$ & yes & no & Leukoplakia & Moderate \\
\hline 18 & $\mathrm{~F}$ & 79 & $\begin{array}{l}\text { Floor of } \\
\text { mouth }\end{array}$ & yes & no & Leukoplakia & Severe \\
\hline
\end{tabular}

Figure 1- Clinical and pathological characteristics of the oral leukoplakia sample

Table 1- Differences in $\beta$-catenin expression in mild, moderate and severe oral dysplasia, and normal oral mucosa (Control) $)^{a, b}$

\begin{tabular}{|c|c|c|c|c|c|c|c|c|c|}
\hline \multirow[t]{2}{*}{ Cytoplasmic localization } & \multicolumn{2}{|c|}{ Mild } & \multicolumn{2}{|c|}{ Moderate } & \multicolumn{2}{|c|}{ Severe } & \multicolumn{2}{|c|}{ Control } & \multirow[t]{2}{*}{$p$} \\
\hline & $\mathbf{n}$ & $\%$ & $\mathbf{n}$ & $\%$ & $\mathrm{n}$ & $\%$ & $\mathrm{n}$ & $\%$ & \\
\hline Basal layer & \multicolumn{2}{|c|}{ A } & \multicolumn{2}{|c|}{$\mathrm{B}, \mathrm{A}$} & \multicolumn{2}{|c|}{ C,A } & \multicolumn{2}{|c|}{$\mathrm{D}, \mathrm{B}, \mathrm{C}$} & \\
\hline Negative & 17 & 89.5 & 2 & 15.4 & - & 0 & 10 & 100 & \\
\hline Positive & 2 & 10.5 & 11 & 84.6 & 7 & 100 & - & 0 & $<0.001$ \\
\hline Total & 19 & 100 & 13 & 100 & 7 & 100 & 10 & 100 & \\
\hline $\begin{array}{c}\text { Basal and Parabasal } \\
\text { layers }\end{array}$ & \multicolumn{2}{|c|}{$A$} & \multicolumn{2}{|c|}{$\mathrm{B}, \mathrm{A}$} & \multicolumn{2}{|c|}{$\mathrm{C}, \mathrm{A}$} & \multicolumn{2}{|c|}{$\mathrm{D}, \mathrm{B}, \mathrm{C}$} & \\
\hline Negative & 19 & 100 & 4 & 30.8 & 1 & 14.3 & 10 & 100 & \\
\hline Positive & - & 0 & 9 & 69.2 & 6 & 85.7 & - & 0 & $<0.001$ \\
\hline Total & 19 & 100 & 13 & 100 & 7 & 100 & 10 & 100 & \\
\hline
\end{tabular}

a Chi-square test

b Equal letters indicate statistical difference by Fisher's Exact Test 

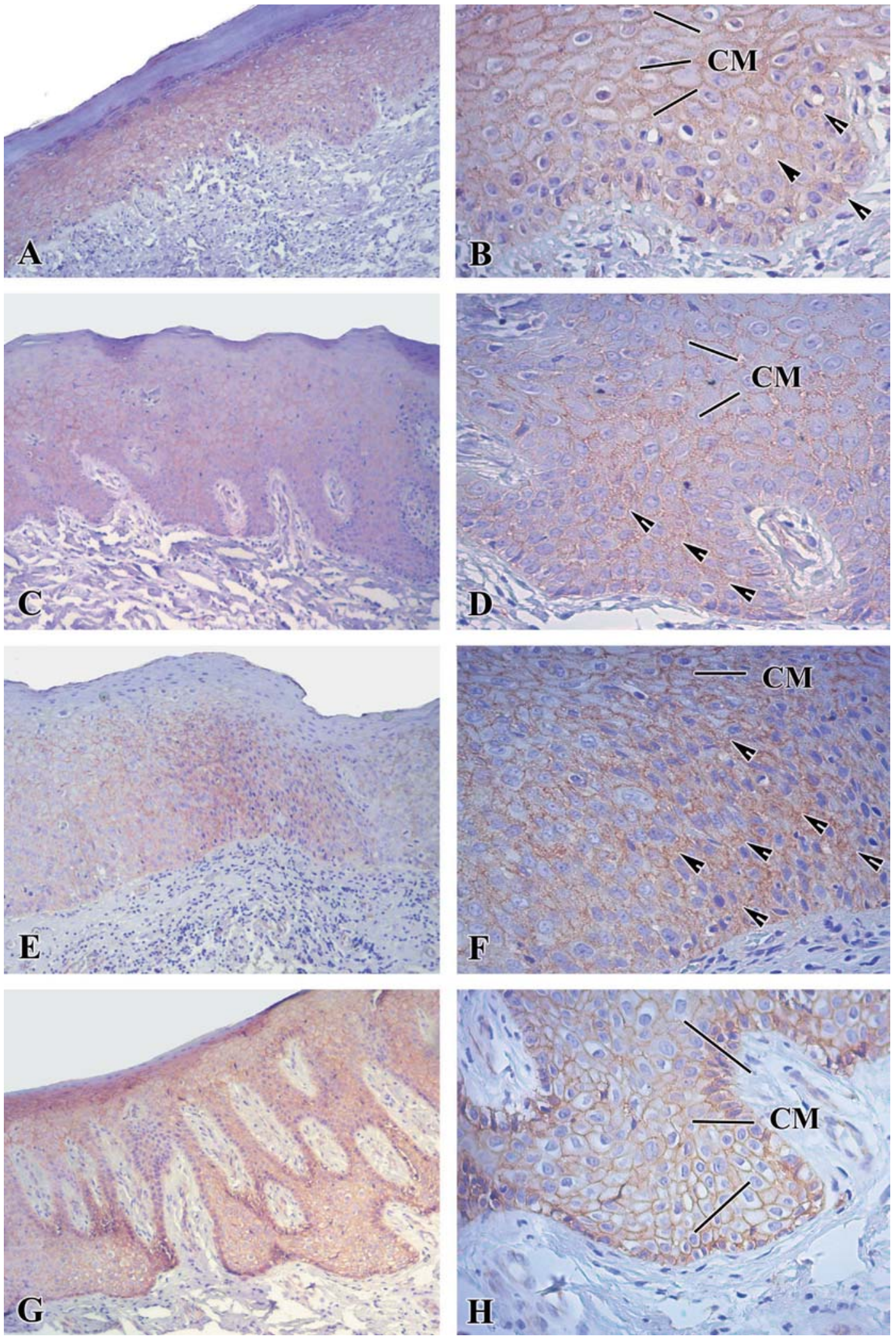

Figure 2- $\beta$-catenin immunohistochemical expression in oral leukoplakia $(\mathrm{OL})$ (mild, moderate and severe dysplasia) and normal oral mucosa. (A) $\beta$-catenin cytoplasmic membrane staining, in all three layers of mild dysplasia (x100), and (B) in the cytoplasm of basal and parabasal cells. $(C, D)$ Illustrations of the $\beta$-catenin cytoplasmic membrane (CM) expression in the upper layers of moderate dysplasia, showing a decrease in cytoplasmic membrane expression, with more evident cytoplasmic localization in basal and parabasal cells (arrows head) (x100 - x400). (E, F) Weak membranous expression of $\beta$-catenin in parabasal and basal layers of severe dysplasia, with a significant increase in its expression, in the cytoplasm (arrows head) of cells of basaloid appearance (x100 - x400). (G, H) $\beta$-catenin in normal oral mucosa $(x 100-x 400)$ 
In normal oral mucosa, $\beta$-catenin was detected only in the cytoplasmic membrane (Figure 2, $\mathrm{G}-\mathrm{H})$. On the other hand, a significant difference in $\beta$-catenin cytoplasmic staining was identified among all the OL groups (Chi Square test $\mathrm{p}<0.001$ ) (Table 1). When specifying these differences in the $\beta$-catenin expression, a significant increase in cytoplasmic $\beta$-catenin could be observed between mild and moderate dysplasia (Fisher Exact test - $p<0.001$ ), mild and severe dysplasia $(p<0.001)$, normal oral mucosa and moderate dysplasia $(p<0.001)$, and oral normal mucosa and severe dysplasia $(p<0.001)$ (Table $1)$. A cytoplasmic $\beta$-catenin expression was clearly detected in cells with a basaloid appearance.

Analyzing the cytoplasmic $\beta$-catenin distribution among epithelial layers, a predominance of basal and parabasal localization of this protein was noted in the highest grades of dysplasia (moderate and severe dysplasia) (Figure 2, C-F). In mild dysplasia, cytoplasmic $\beta$-catenin staining was found only in the basal layer (Figure 2, A-B; Table 1).

\section{DISCUSSION}

$\beta$-catenin is an adhesion molecule that interacts with E-cadherin through its cytoplasmic domain. The E-cadherin-catenin complex disruption from cell membrane seems to be important in malignant transformation ${ }^{9,14-16,22,25,27-29}$, and interferences in this complex could lead to $\beta$-catenin cytoplasmic accumulation and consequent nuclear translocation ${ }^{21,27}$. This altered localization is related to the activation of some genes involved in cell proliferative activities ${ }^{2}$, malignant transformation and tumor progression ${ }^{24}$. Accordingly, the Twist protein seems to play an important role in E-cadherin repression, also linked to $\beta$-catenin altered expression ${ }^{8,11,24}$ through the Wnt pathway ${ }^{30-32}$. The altered expression of E-cadherin immunoexpression found in epithelial dysplasia, and the possible role of Twist in oral malignant transformation, found in our previous reports $8,26,30$, led us to investigate the $\beta$-catenin immunohistochemical in oral leukoplakia (OL) with different degrees of epithelial dysplasia.

In this study, we observed an altered (cytoplasmic) $\beta$-catenin immunoexpression among OL dysplastic groups. In our previous report, we showed a gradual decrease in E-cadherin immunoexpression in the basal and parabasal cell layers, as the degree of dysplasia increased ${ }^{8}$. Interestingly, in the present investigation we found a similar inverse pattern, with a predominance of basal and parabasal localization of cytoplasmic $\beta$-catenin, and with an intensification of its expression concomitantly with OL progression to a more severe grade of dysplasia. This could indicate the presence of disturbances in the E-cadherincatenin complex in $\mathrm{OL}$, thus indicating that losses of E-cadherin and $\beta$-catenin abnormal expressions are early events of oral carcinogenesis.

In this case, it is plausible to assume that cytoplasmic $\beta$-catenin could participate in oral malignant transformation, insofar as its cytoplasmic accumulation has been demonstrated in different tumours ${ }^{19}$ and also in oral epithelium with dysplastic changes ${ }^{15,25}$. Although nuclear $\beta$-catenin is considered a solid sign of pathway deregulation 12,25 , it is reasonable to presume that the cytoplasmic $\beta$-catenin localization found in the present study is an event that precedes $\beta$-catenin translocation to the nucleus. Theoretically, this may be attributed to activation of the Wnt pathway that inhibits phosphorylation and degradation of $\beta$-catenin, and that induces its cytoplasmic accumulation ${ }^{2}$. Additionally, downregulation of membranous E-cadherin with cytoplasmic accumulation of $\beta$-catenin has been previously reported in several tumors 6 .

Recently, a few studies have also found increased $\beta$-catenin cytoplasmic accumulation in oral dysplasia ${ }^{15,19,25}$. Nevertheless, the exact role of catenin expression in oral malignant transformation is still uncertain. Ishida, et al. ${ }^{12}$ (2007) observed $\beta$-catenin expression in the cell membrane and the cytoplasm of $24 \%$ of basal and spinous cells of oral leukoplakia without dysplasia. However, they also found significant nuclear $\beta$-catenin expression in more than $80 \%$ of epithelial cells of oral leukoplakia with dysplasia. Additionally, it was noted that the nuclear expression of $\beta$-catenin in epithelia increased depending on the grade of dysplasia.

Lo Muzio, et al. ${ }^{19}$ (2009) evaluated the immunohistochemical staining of $\beta$-catenin and $\beta$-catenin in 49 cases of oral epithelial dysplasia and in 10 samples of normal oral mucosa. As in the present study, they described that when the catenin expression was lost, a cytoplasmic delocalization occurred. However, they were not able to find significant differences in the catenin expression between cases that progressed to oral squamous cell carcinoma (OSCC) and cases that did not.

In cases of carcinoma in situ, Alvarado, et al. ${ }^{1}$ (2011) observed $\beta$-catenin in the nucleus of cells with a basaloid appearance and a diffusely $\beta$-catenin expression in the cytoplasm of lowerhalf basaloid cells. Although they considered the nuclear expression of $\beta$-catenin a sign of its nuclear translocation, they also mentioned that $\beta$-catenin had been previously found restricted to the cytoplasm in OSCC samples. In the present investigation, we found a similar cytoplasmic expression in basaloid cells in lower-half of $\mathrm{OL}$ 
dysplastic epithelia. This could indicate that cytoplasmic accumulation of $\beta$-catenin participates in the acquisition of a more motile phenotype.

In a recent study, Schussel, et al. ${ }^{25}$ (2011) evaluated cases of actinic cheilitis (AC) and squamous cell carcinoma (SCC) of the lip, and observed that most cases of AC showed both membrane and cytoplasmic expression of $\beta$-catenin, with only $22 \%$ expressing $\beta$-catenin in the nucleus.

Our data showed that membranous expression of $\beta$-catenin in parabasal and basal layers was gradually lost in the higher degrees of epithelial dysplasia. In addition, a significant difference in $\beta$-catenin cytoplasmic staining was identified among all the OL groups.

\section{CONCLUSIONS}

The $\beta$-catenin cytoplasmic expression observed in this study may represent the initial stage of modifications in the E-cadherin-catenin complex, along with morphological cellular changes. We suggest that this cellular mechanism could be associated with Twist overexpression through the Wnt pathway. Further studies are needed to test this hypothesis.

\section{ACKNOWLEDGEMENTS}

The authors are grateful to Mr. Gercino Monteiro Filho for his assistance with the statistical analyses presented in the manuscript.

\section{REFERENCES}

1- Alvarado CG, Maruyama S, Cheng J, Ida-Yonemochi H, Kobayashi T, Yamazaki M, et al. Nuclear translocation of beta-catenin synchronized with loss of E-cadherin in oral epithelial dysplasia with a characteristic two-phase appearance. Histopathology. 2011;59(2):283-91.

2- Barker N, Clevers H. Catenins, Wnt signaling and cancer. Bioessays. 2000;22(11):961-5.

3- Barnes L EJ, Reichart PA, Sidranskiy D, eds. World Health Organization classification of tumours, pathology and genetics of head and neck tumours. $1^{\text {st }}$ ed. Lyon: IARC Press; 2005. $430 \mathrm{p}$. 4- Baum B, Georgiou M. Dynamics of adherens junctions in epithelial establishment, maintenance, and remodeling. J Cell Biol. 2011;192(6):907-17.

5- Birchmeier W, Behrens J. Cadherin expression in carcinomas: role in the formation of cell junctions and the prevention of invasiveness. Biochim Biophys Acta. 1994;1198(1):11-26.

6- Brembeck FH, Rosário M, Birchmeier W. Balancing cell adhesion and Wnt signaling, the key role of beta-catenin. Curr Opin Genet Dev. 2006;16(1):51-9.

7- Clevers $\mathrm{H}$. Wnt/beta-catenin signaling in development and disease. Cell. 2006;127(3):469-80.

8- Freitas Silva BS, Yamamoto-Silva FP, Pontes HA, Pinto Júnior DS. E-cadherin downregulation and Twist overexpression since early stages of oral carcinogenesis. J Oral Pathol Med. 2014;43(2):125-31.
9- Galera-Ruiz H, Ríos-Moreno MJ, González-Cámpora R, Ortega I, Fernández A, García-Escudero A, et al. The cadherin-catenin complex in laryngeal squamous cell carcinoma. Eur Arch Otorhinolaryngol. 2012;269(4):1183-8.

10- Hirshberg A, Shnaiderman-Shapiro A, Kaplan I, Berger R. Metastatic tumours to the oral cavity - pathogenesis and analysis of 673 cases. Oral Oncol. 2008;44(8):743-52.

11- Howe LR, Watanabe O, Leonard J, Brown AM. Twist is upregulated in response to Wnt 1 and inhibits mouse mammary cell differentiation. Cancer Res. 2003;63(8):1906-13.

12- Ishida K, Ito S, Wada N, Deguchi H, Hata T, Hosoda M, et al. Nuclear localization of beta-catenin involved in precancerous change in oral leukoplakia. Mol Cancer. 2007;6:62.

13- Jouppila-Mättö A, Närkiö-Mäkelä $M$, Soini $Y$, Pukkila $M$, Sironen $\mathrm{R}$, Tuhkanen $\mathrm{H}$, et al. Twist and snai1 expression in pharyngeal squamous cell carcinoma stroma is related to cancer progression. BMC Cancer. 2011;11:350.

14- Karim R, Tse G, Putti T, Scolyer R, Lee S. The significance of the Wnt pathway in the pathology of human cancers. Pathology. 2004;36(2):120-8.

15- Kaur J, Sawhney M, DattaGupta S, Shukla NK, Srivastava A, Walfish PG, et al. Clinical significance of altered expression of betacatenin and E-cadherin in oral dysplasia and cancer: potential link with ALCAM expression. PLoS One. 2013;8(6): e67361.

16- Kooy AJ, Tank B, de Jong AA, Vuzevski VD, van der Kwast $\mathrm{TH}$, van Joost $\mathrm{T}$. Expression of E-cadherin, alpha- \& beta-catenin, and CD44V6 and the subcellular localization of E-cadherin and CD44V6 in normal epidermis and basal cell carcinoma. Hum Pathol. 1999;30(11):1328-35.

17- Kyrodimou M, Andreadis D, Drougou A, Amanatiadou EP, Angelis L, Barbatis $C$, et al. Desmoglein-3/gamma-catenin and $\mathrm{E}$-cadherin/beta-catenin differential expression in oral leukoplakia and squamous cell carcinoma. Clin Oral Investig. 2014;18(1):199-210.

18- Liu F, Millar SE. Wnt/beta-catenin signaling in oral tissue development and disease. J Dent Res. 2010;89(4):318-30.

19- Lo Muzio L, Lo Russo L, Falaschini S, Ciavarella D, Pentenero $M$, Arduino $P$, et al. Beta- and gamma-catenin expression in oral dysplasia. Oral Oncol. 2009;45(6):501-4.

20- Luo GQ, Li JH, Wen JF, Zhou YH, Hu YB, Zhou JH. Effect and mechanism of the Twist gene on invasion and metastasis of gastric carcinoma cells. World J Gastroenterol. 2008;14(16):2487-93. 21- Lustig B, Behrens J. The Wnt signaling pathway and its role in tumor development. J Cancer Res Clin Oncol. 2003;129(4):199221.

22- Morrogh M, Andrade VP, Giri D, Sakr RA, Paik W, Qin LX, et al. Cadherin-catenin complex dissociation in lobular neoplasia of the breast. Breast Cancer Res Treat. 2012;132(2):641-52.

23-Pectasides E, Rampias T, Sasaki C, Perisanidis C, Kouloulias V, Burtness B, et al. Markers of epithelial to mesenchymal transition in association with survival in head and neck squamous cell carcinoma (HNSCC). PLoS One. 2014;9(4):e94273.

24- Ravindran G, Devaraj H. Aberrant expression of betacatenin and its association with DeltaNp63, Notch-1, and clinicopathological factors in oral squamous cell carcinoma. Clin Oral Investig. 2012;16(4):1275-88.

25- Schussel JL, Pinto DS Jr, Martins MT. Altered beta-catenin expression related to cancer progression on actinic cheilitis and squamous cell carcinoma of the lip. Ann Diagn Pathol. $2011 ; 15(1): 1-5$.

26- Silva BS, Yamamoto FP, Pontes FS, Vieira-Cury SE, Fonseca FP, Pontes HA, et al. TWIST and p-Akt immunoexpression in normal oral epithelium, oral dysplasia and in oral squamous cell carcinoma. Med Oral Patol Oral Cir Bucal. 2012;17(1):e29-34. 27- Soares MQ, Mendonça JA, Morais MO, Leles CR, Batista AC, Mendonça EF. E-cadherin, $\beta$-catenin, and $a 2 \beta 1$ and a $3 \beta 1$ integrin expression in primary oral squamous cell carcinoma and its regional metastasis. Histol Histopathol. 2015:11616. 
28- Takayama $T$, Shiozaki $H$, Shibamoto $S$, Oka $H$, Kimura $Y_{\text {, }}$ Tamura $\mathrm{S}$, et al. Beta-catenin expression in human cancers. Am J Pathol. 1996;148(1):39-46.

29- Utsunomiya T, Doki Y, Takemoto $H$, Shiozaki $H$, Yano $M$, Inoue $M$, et al. Clinical significance of disordered beta-catenin expression pattern in human gastric cancers. Gastric Cancer. 2000;3(4):193-201.

30- Von Zeidler SV, Souza Botelho T, Mendonça EF, Batista AC. $\mathrm{E}$-cadherin as a potential biomarker of malignant transformation in oral leukoplakia: a retrospective cohort study. BMC Cancer. 2014;14:972.
31- Wallerand H, Robert G, Pasticier G, Ravaud A, Ballanger $P$, Reiter RE, et al. The epithelial-mesenchymal transition-inducing factor TWIST is an attractive target in advanced and/or metastatic bladder and prostate cancers. Urol Oncol. 2010;28(5):473-9. 32- Watanabe O, Imamura $\mathrm{H}$, Shimizu T, Kinoshita J, Okabe T, Hirano $A$, et al. Expression of twist and wnt in human breast cancer. Anticancer Res. 2004;24(6):3851-6. 